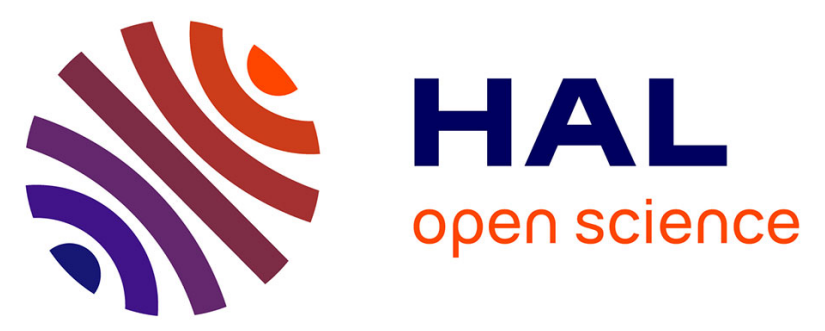

\title{
Redescription and molecular characterisation of Allogastrocotyle bivaginalis Nasir \& Fuentes Zambrano, 1983 (Monogenea: Gastrocotylidae) from Trachurus picturatus (Bowdich) (Perciformes: Carangidae) off the Algerian coast, Mediterranean Sea
}

Chahinez Bouguerche, Fadila Tazerouti, Delphine Gey, Jean-Lou Justine

\section{To cite this version:}

Chahinez Bouguerche, Fadila Tazerouti, Delphine Gey, Jean-Lou Justine. Redescription and molecular characterisation of Allogastrocotyle bivaginalis Nasir \& Fuentes Zambrano, 1983 (Monogenea: Gastrocotylidae) from Trachurus picturatus (Bowdich) (Perciformes: Carangidae) off the Algerian coast, Mediterranean Sea. Systematic Parasitology, 2019, 96 (8), pp.681-694. 10.1007/s11230-019-09883-7. hal-02557974

\author{
HAL Id: hal-02557974 \\ https://hal.science/hal-02557974
}

Submitted on 29 Apr 2020

HAL is a multi-disciplinary open access archive for the deposit and dissemination of scientific research documents, whether they are published or not. The documents may come from teaching and research institutions in France or abroad, or from public or private research centers.
L'archive ouverte pluridisciplinaire HAL, est destinée au dépôt et à la diffusion de documents scientifiques de niveau recherche, publiés ou non, émanant des établissements d'enseignement et de recherche français ou étrangers, des laboratoires publics ou privés. 
Systematic Parasitology (2019) 96:681-694

DOI: 10.1007/s11230-019-09883-7

Redescription and molecular characterisation of

Allogastrocotyle bivaginalis Nasir \& Fuentes Zambrano, 1983

(Monogenea: Gastrocotylidae) from Trachurus picturatus

(Bowdich) (Perciformes: Carangidae) off the Algerian coast,

\section{Mediterranean Sea}

Chahinez Bouguerche $^{\text {a }}$, Fadila Tazerouti ${ }^{a}$,Delphine Gey ${ }^{b}$, Jean-Lou Justine ${ }^{c}$

a Université des Sciences et de la Technologie Houari Boumediene, Facultẻ des Sciences

Biologiques, Laboratoire de Biodiversité et Environnement: Interactions - Génomes, BP 32, El

Alia Bab Ezzouar, Alger, Algeria

b Service de Systématique moléculaire, UMS 2700 CNRS, Muséum National d'Histoire Naturelle, Sorbonne Université, CP 26, 43 rue Cuvier, 75231 Paris Cedex 05, France

c Institut Systématique Évolution Biodiversite̋ (ISYEB), Muséum National d'Histoire Naturelle, CNRS, Sorbonne Université, EPHE, Université des Antilles, 57 rue Cuvier, CP 51, 75005 Paris, France

Corresponding author: e-mail: justine@mnhn.fr 


\begin{abstract}
Allogastrocotyle bivaginalis Nasir \& Fuentes Zambrano, 1983, the sole species of Allogastrocotyle Nasir \& Fuentes Zambrano, 1983, was described from Trachurus lathami Nichols off Venezuela and never recorded since. We found monogeneans on Trachurus picturatus (Bowdich) (Carangidae) off the Algerian coast, Mediterranean Sea, which had the characteristics of the genus, including, especially, paired vaginae. We compared them to the single available specimen of A. bivaginalis, the holotype. Unfortunately, this holotype does not show clamp structure and soft internal anatomy. Our specimens were similar to A. bivaginalis in most characteristics such as body shape, vaginal openings, and number of testes, clamps and hooks in genital atrium. We detected minor differences in clamp structure but could not ascertain if these were the result of incomplete observations in the original description of real morphological differences. The host fish of our specimens were barcoded (cox1) confirming their specific identity. A phylogenetic analysis of cox 1 sequences showed that our sequences of $A$. bivaginalis were distinct from those of Pseudaxine trachuri Parona \& Perugia, 1889 (distance> 15\%) and of several other gastrocotylids. Finally, we could not distinguish our Mediterranean specimens from A. bivaginalis, neither on the base of morphology (because the original description is incomplete) nor on molecules (because molecular information is lacking on A. bivaginalis from Venezuela) and ascribe them to A. bivaginalis. However, hosts are different, and localities are widely separated, so it is likely that future study will show that the species from the Mediterranean is a distinct, new, species.
\end{abstract}




\section{Introduction}

The Gastrocotylidae Price, 1943 was erected to separate Gastrocotyle Van Beneden \& Hesse, 1863 by reference to a diagram of the clamp type alone (Price, 1943; Hargis, 1956). Sproston (1946) agreed on the importance of the difference in clamp structure in microcotylids but she reduced the Gastrocotylidae to subfamily status, as Gastrocotylinae included in the Microcotylidae Taschenberg, 1879 (see Sproston, 1946). Palombi (1949) did not recognise Sproston's Gastrocotylinae and placed its members in the subfamily Microcotylinae Monticelli, 1892 in his own family Arreptocotylidae Palombi, 1949 (see Palombi, 1949). Hargis (1956) recognised the Gastrocotylidae with the subfamilies Gastrocotylinae Sproston, 1946 and Vallisiinae Price, 1943 (see Hargis 1956); Gastrocotyle Van Beneden \& Hesse, 1863 was designated as the type-genus (Hargis, 1956). Lebedev (1986) recognised 16 genera in the family. Currently, the Gastrocotylidae include about 20 genera (WoRMS, 2019), the most recently described being Allogastrocotyle Nasir \& Fuentes Zambrano, 1983, erected to accommodate Allogastrocotyle bivaginalis Nasir \& Fuentes Zambrano, 1983 from the gills of Trachurus lathami off Venezuela (Nasir $\&$ Fuentes Zambrano, 1983). This species has never been recorded since its original description. In the course of a parasitological study of monogeneans of fishes off the southern coast of the Mediterranean Sea (Chaabane et al. 2015, 2016a, b, 2017; Kheddam et al., 2016; Ayadi et al., 2017; Derouiche et al., 2019; Bouguerche et al., 2019a, b), we collected representatives of a monogenean similar to A. bivaginalis on the gills of the blue jack mackerel Trachurus picturatus (Bowdich). The specimens are described here and compared to the holotype of A. bivaginalis. Because their general body shapes are somewhat similar, we also compared sequences of our specimens with Pseudaxine trachuri Parona \& Perugia, 1889 off the Algerian coast.

\section{Materials and methods}

\section{Fishes}

During 2016 and 2018, 241 specimens of Trachurus picturatus were collected off Zemmouri El Bahri

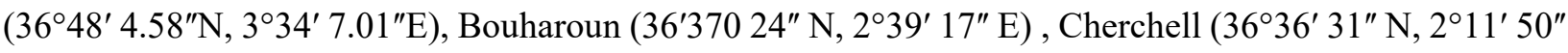
E), Dellys (36 $\left.54^{\prime} 48^{\prime \prime} \mathrm{N}, 3^{\circ} 54^{\prime} 51^{\prime \prime} \mathrm{E}\right)$ and Cap Djinet (36 $\left.52^{\prime} 37^{\prime \prime} \mathrm{N}, 3^{\circ} 43^{\prime} 23^{\prime \prime} \mathrm{E}\right)$ off the Algerian coast. Fish specimens were transferred to the laboratory shortly after capture and identified using keys (Fischer et al., 1987). Gills were removed from each fish and were observed under microscope for the presence of 
monogeneans.

\section{Monogeneans: morphological methods}

Monogeneans were removed alive from gills using fine dissection needles, then fixed in $70 \%$ ethanol, stained with acetic carmine, dehydrated in ethanol series (70, 96 and 100\%), cleared in clove oil, and mounted in Canada balsam. Drawings were made with the help of an Olympus BH-2 microscope with a drawing tube. Drawings were scanned and redrawn on a computer with Adobe Illustrator (CS5). Measurements are in micrometres, and indicated as the range followed by the mean \pm standard deviation if $\mathrm{n}>30$ and the number of measurements in parentheses.

\section{Monogeneans: molecular methods}

To ensure that hosts and monogeneans were labelled with respect of host-parasites relationships we followed recent studies dealing with description of new species of Monogenea using barcoding (Justine et al., 2013; Ayadi et al., 2017; Bouguerche et al., 2019a, b). For each host fish from which monogeneans were collected, a tissue sample from the gills was taken. The monogeneans were cut in three parts using a scalpel blade. Their anterior part (which includes the genital atrium) and posterior part (which includes the haptor) of each specimen were mounted as vouchers (both parts on a single slide) for drawing and deposition in a museum collection; their median parts were fixed in absolute ethanol then subjected to molecular analyses. Two specimens were analysed.

\section{Molecular barcoding of fishes}

Total genomic DNA was isolated using QIAamp DNA Mini Kit (Qiagen, Courtaboeuf, France) as per the manufacturer's instructions. The $5^{\prime}$ region of the mitochondrial cytochrome $\mathrm{c}$ oxidase subunit 1 (cox 1$)$ gene was amplified with the primers FishF1 (5'-TCA ACC AAC CAC AAA GAC ATT GGC AC-3') and FishR1 (5'-TAG ACT TCT GGG TGG CCA AAG AAT CA-3') (Ward et al., 2005). PCR reactions were performed in $20 \mu$ l, containing $1 \mathrm{ng}$ of DNA, $19 \times$ CoralLoad PCR buffer, $3 \mathrm{mM} \mathrm{MgCl} 2,66 \mu \mathrm{M}$ of each dNTP, $0.15 \mu \mathrm{M}$ of each primer, and 0.5 units of Taq DNA polymerase (Qiagen). The amplification protocol was $4 \mathrm{~min}$ at $94^{\circ} \mathrm{C}$, followed by 40 cycles at $94^{\circ} \mathrm{C}$ for $30 \mathrm{~s}, 48^{\circ} \mathrm{C}$ for $40 \mathrm{~s}$, and $72^{\circ} \mathrm{C}$ for $50 \mathrm{~s}$, with a final extension step at $72^{\circ} \mathrm{C}$ for $7 \mathrm{~min}$. PCR products were purified (Ampure XP Kit, Beckman Coulter) 
and sequenced in both directions on a 3730x1 DNA Analyzer 96-capillary sequencer (Applied Biosystems, Foster City, USA). We used CodonCode Aligner version 3.7.1 software (Codon Code Corporation, Dedham, MA, USA) to edit sequences, compared them to the GenBank database content with BLAST, and deposited them in GenBank under the accession numbers MN192395-MN192399 (Trachurus picturatus, 5 specimens) and MN192400-MN192401 (Trachurus trachurus, 2 specimens). Species identification was confirmed with the BOLD identification engine (Ratnasingham \& Hebert, 2007).

\section{cox1 sequences of monogeneans}

Total genomic DNA was isolated using QIAmp DNA Micro Kit (Qiagen). The specific primers JB3 (=COIASmit1) (forward 5'-TTT TTT GGG CAT CCT GAG GTT TAT-3') and JB4.5 (=COI-ASmit2) (reverse 5'-TAA AGA AAG AAC ATA ATG AAA ATG-3') were used to amplify a fragment of $424 \mathrm{bp}$ of the cox 1 gene (Bowles et al., 1995; Littlewood et al., 1997). PCR reaction was performed in $20 \mu 1$, containing $1 \mathrm{ng}$ of DNA, $1 \times$ CoralLoad PCR buffer, $3 \mathrm{mM} \mathrm{MgCl} 2,0.25 \mathrm{mM}$ dNTP, $0.15 \mu \mathrm{M}$ of each primer, and 0.5 units of Taq DNA polymerase (Qiagen). Thermocycles consisted of an initial denaturation step at $94^{\circ} \mathrm{C}$ for $2 \mathrm{~min}$, followed by 37 cycles of denaturation at $94^{\circ} \mathrm{C}$ for $30 \mathrm{~s}$, annealing at $48^{\circ} \mathrm{C}$ for 40 $\mathrm{s}$, and extension at $72^{\circ} \mathrm{C}$ for $50 \mathrm{~s}$. The final extension was conducted at $72^{\circ} \mathrm{C}$ for $5 \mathrm{~min}$. Sequences were edited with CodonCode Aligner software version 3.7.1 (CodonCode Corporation, Dedham, MA, USA), com- pared to the GenBank database content with BLAST, and deposited in GenBank under the accession numbers MN192391-MN192394.

\section{Trees and distances}

Most sequences of Gastrocotylidae available on GenBank were included in the phylogenetic analyses, but we did not use very short sequences or sequences without host identification. Two new sequence of Pseudaxine trachuri Parona \& Perugia, 1889 from the type-host Trachurus trachurus off Algeria were also added. Sequences of two Gotocotylidae Yamaguti,1963 were used as the outgroup. The trees were inferred using the Neighbour-Joining (NJ) method and the Maximum Likelihood (ML) method using MEGA7 (Kumar et al., 2016). For the latter, the best model, estimated in MEGA7, was the HasegawaKishino-Yano model (Hasegawa et al., 1985) with discrete Gamma distribution (HKY + G). Genetic distances (p-distance and Kimura-2 parameter distance, Kimura, 1980) were estimated with MEGA7. All codon positions were used. 


\section{Results}

\section{Molecular identification of fish}

The provisional identification of fish species using morphological characteristics was confirmed by DNA barcoding approach. BLAST analysis of the cox 1 sequences of fish species of the present study with NCBI and BOLD database showed sequence similarity values of $99.69 \%$ for Trachurus picturatus and 99.85\% for Trachurus trachurus.

\section{Molecular characterisation of monogeneans}

The analysis involved 9 nucleotide sequences (Table 1). The cox1 sequences of $A$. bivaginalis were aligned with sequences of three other gastrocotylid species and two gotocotylids. The NJ and ML methods led to slightly different topologies and thus only the ML tree is shown (Fig. 1); these differences concerned only the relative position of the two basal species Pellonicola elongatus and Engraulicola thrissocles. The Gastrocotylidae formed a monophyletic group separated from the outgroups. Within the gastrocotylid clade, a robust clade included all sequences of Pseudaxine trachuri [bootstrap support: $99 \%$ (NJ) and 97\% (ML)]. Another clade, with high support, included our sequences of Allogastrocotyle bivaginalis $(100 \% \mathrm{NJ}$ and $99 \% \mathrm{ML})$. The $P$. trachuri and the A. bivaginalis clades were sister-groups $(78 \% \mathrm{NJ}$ and $79 \% \mathrm{ML})$.

Distances were computed using p-distance and Kimura-2 parameter (Tables 2, 3). The differences were minor, and both are commented here. The two sequences of A. bivaginalis were identical. Distances between the sequences for $A$. bivaginalis and those for $P$. trachuri were $15-16 \%$ (p-distance) and $17-18 \%$ (Kimura-2 parameter). This clearly demonstrates that the Allogastrocotyle species is distinct from $P$. trachuri. 
Family Gastrocotylidae Price, 1943

Genus Allogastrocotyle Nasir \& Fuentes Zambrano, 1983

\section{Allogastrocotyle bivaginalis Nasir \& Fuentes Zambrano, 1983}

Type-host: Trachurus lathami Nichols (Perciformes: Carangidae).

Other host: Trachurus picturatus (Bowdich) (Carangidae), blue jack mackerel (this paper).

Type-locality: Gulf of Cariaco, Venezuela.

Other localities: off Zemmouri el Bahri (36 $\left.48^{\prime} 4.58^{\prime \prime} \mathrm{N}, 3^{\circ} 34^{\prime} 7.01^{\prime \prime} \mathrm{E}\right)$, Bouharoun (36 $37^{\prime} 24^{\prime \prime} \mathrm{N}, 2^{\circ} 39^{\prime}$ 17" E), Cherchell (36 $\left.36^{\circ} 31^{\prime \prime} \mathrm{N}, 2^{\circ} 11^{\prime} 50^{\prime \prime} \mathrm{E}\right)$, Dellys (36 $\left.54^{\prime} 48^{\prime \prime} \mathrm{N}, 3^{\circ} 54^{\prime} 51^{\prime \prime} \mathrm{E}\right)$ and Cap Djinet $\left(36^{\circ} 52^{\prime}\right.$ $37^{\prime \prime} \mathrm{N}, 3^{\circ} 43^{\prime} 23^{\prime \prime} \mathrm{E}$ ), off the Algerian coast (this paper).

Type-specimens: Holotype, USNPC 75594, USNM 1371132 (examined).

Specimens from Algeria: Vouchers deposited in the collections of the Muséum National d'Histoire Naturelle, Paris (MNHN HEL1091-HEL1092 and HEL1095-HEL1104) and in the USNM (15926181592621).

Representative DNA sequences: cox1 (GenBank: MN192391, voucher MNHN HEL1091, and Gen- Bank: MN192392, voucher MNHN HEL1092, both from fish barcoded as GenBank MN192399). Vouchers represent anterior and posterior parts of specimens mounted together on slide, the median part used for molecular analysis.

Site on host: Gills.

Prevalence and intensity: Ex Trachurus picturatus off Algeria: 27\% (57 out of 214 fish), up to 2 monogeneans/fish (this paper).

Comparative material studied: Vouchers of Pseudaxine trachuri from the type-host, Trachurus trachurus, off Algeria, including two specimens with molecular information (MNHN HEL1093, GenBank: MN192393 and MNHN HEL1094, GenBank: MN192394, both from fish barcoded as GenBank MN192401). 


\section{Redescription of the holotype (Fig. 2)}

[Measurements in Table 4.] Body elongate, typically gastrocotylid, anterior extremity constricted. Haptor long, unilateral, asymmetrical, armed with clamps arranged in single row, enclosed in clamp capsule supported by short peduncles which have axial muscle bundles. Number of clamps 32 (31 clamps present, anteriormost as broken peduncle). Structure of clamps indistinct, peduncle present. Terminal lappet present, armed with 2 pairs of anchors: small, posteriormost anchor pair and large anteriormost anchor pair; anterior anchors sickle-shaped and parallel. Pair of prohaptoral suckers sub-spherical, muscular, septate. Pharynx roughly pyramidal. Oesophagus bifurcating posterior to genital atrium. Intestinal branches extending to posterior body extremity, obscured by staining. Testes post-ovarian, number indistinct; genital atrium armed with hooks, obliquely oriented; hooks indistinct. Atrial hooks as in Fig. 2, their number probably 12. Ovary pretesticular, folded, other details indistinct. Vaginal openings visible, ventrolateral in anterior narrowed part of body, slightly posterior to the genital atrium, anterior to bifurcation of oesophagus; vaginal openings unarmed, with irregular shape. Vaginal ducts not seen. One abnormal egg in uterus, elongated with two filaments, total length 430 (Fig. 2).

\section{Remarks}

The holotype is in good state but was unflattened and overstained, therefore obscuring most details of internal anatomy. In addition, most clamps are oriented laterally, precluding redescription of their structure.

\section{Description of specimens from Trachurus picturatus off Algeria (Figs. 3-6)}

[Based on 32 specimens. Measurements in Table 4.] Body elongate, typically gastrocotylid, anterior extremity constricted. Haptor long, unilateral, asymmetrical, with single row of clamps. Clamps enclosed in clamp capsule, pedunculated; peduncles with short axial muscle bundles (Fig. 4C). Clamps typically gastrocotylid; ventral arm of median spring Y shaped, long and relatively narrow, proximal end of ventral arm of median spring very wide, its distal part Y-shaped, each limb abutting on short oblique sclerites, close to ventral jaw but not reaching it; dorsal arm of median spring wider than ventral, distally broad, with 3-4 pairs of apertures arranged in 2 longitudinal symmetrical parallel rows, distal end of dorsal arm with accessory skeletal piece represented by V-shaped process at its distal end (Fig. 6). Dorsal arm of ventral jaw short and curved inwards and almost reaching accessory skeletal piece of dorsal arm of median spring. 
Dorsal jaw shorter than ventral. Oblique sclerites longer, with inner ends touching each other along median line. Base of clamp with cuticularised hinge ligament on each side, connecting median spring with base of the jaw sclerites (Fig. 6).

Terminal lappet present (Fig. 4B), armed with 2 symmetrical pairs of gastrocotyloid anchors, dissimilar in shape and size: small, posteriormost anchor pair (Fig. 4E); large anteriormost anchor pair sickle- shaped and parallel (Fig. 4D). Pair of prohaptoral suckers subspherical, muscular, septate. Pharynx oval. Intestinal branches extending almost to posterior body extremity, not confluent, each branch with outer and inner ramifications (Fig. 4A).

Testes post-ovarian, relatively large, oval, arranged irregularly in posterior third of body and confined to intercrural field. Vas deferens runs forward along body midline; at level just anterior to genital atrium, swells to voluminous mid-ventral seminal vesicle (Fig. 4F, I), dorsal to uterus. Genital atrium ventral, with muscular rim, located in anterior restriction of body. Penis conical, slender, armed with circle of gastro- cotylid-like atrial hooks (Fig. 4F-I). Atrial hooks narrowing slightly at their distal ends (Fig. 4G) with bases of hooks with curved tips; "roots" of hooks extend sometimes over outer surface of proximal part of muscular genital atrium; shafts lie near penis, with curved, pointed tips directed inwards (Fig. 4FH). In flattened whole-mounts, penis occasionally tilted, appears as pair of slender spines (Fig. 4F, I).

Ovary pretesticular in form of an inverted U. Ovary begins at level of anteriormost testes, continues anteriorly in midline, reflexes at level of confluence of vitelline ducts, and runs backwards toward haptor to end as oviduct. Oviduct arises from distal end of ovary and opens into ootype with Mehlis gland-cells. Uterus, originating from ootype, runs forwards. Genito-intestinal canal short, dorsal to ootype . Vitellarium follicular, vitelline fields co-extensive with intestinal branches, extending from level of genital atrium to haptor. Transverse vitelloducts short and thick in some specimens, fusing in midline ventral to ovary, to form relatively large, Y-shaped vitelline reservoir (Fig. 5). Vaginal openings visible in all specimens, always paired, ventrolateral in anterior narrowed part of body, posterior to genital atrium; vaginal openings unarmed, with irregular shape (Fig. 4A). Vaginal ducts not seen.

\section{Remarks}

The species was described by Nasir \& Fuentes Zambrano (1983) based on an unknown number of specimens; measurements were given for only two, and a single specimen, designated as the holotype, 
was deposited in the United States Parasite Collection (now in the National Museum of Natural History, Washington, USA). Therefore, a single specimen is available, which we examined. As stated above, overstaining precludes any attempt at redescribing the internal soft anatomy of this unflattened specimen

Our specimens from T. picturatus from off Algeria are similar to the original description in the following characteristics body length body width haptor length number of testes, number of clamps, number of numberof atrial hooks number of anchors in the lappet. Most importantly, our specimens clearly show two vaginal openings, a feature mentioned in the original description and that we could verify on the holotype.

We could distinguish differences between our specimens and the original description in clamp structure. In the original description, ends of limbs of the distal part of the ventral arm of the median spring articulate with the lateral marginal sclerite, in the drawing (figure 4 in Nasir \& Fuentes Zambrano, 1983), the limbs touch the ventral jaws. In our specimens, the limbs abutt on the short oblique sclerites, close to the ventral jaw but not reaching it. In our specimens, an accessory skeletal piece represented by a projecting V-shaped process was observed on the distal end of the dorsal arm that was not mentioned nor illustrated in the type-material.

Some differences between the original description and our observations justify the need to emend the generic diagnosis: intestine branches are not confluent, and the ejaculatory bulb and penis were not described.

\section{Allogastrocotyle Nasir \& Fuentes Zambrano, 1983}

\section{Emended generic diagnosis}

Gastrocotylidae, Gastrocotylinae. Body with slight depression at level of intestinal bifurcation. Haptor unilateral, asymmetrical, consisting of row of numerous clamps and terminal lappet. Clamps of Gastrocotyle-type, pedunculated; terminal lappet armed with two symmetrical pairs of anchors. Paired prohaptoral suckers muscular; pharynx oval, large; intestine with lateral diverticula, extend into haptor. Testes post- ovarian, follicular; ejaculatory bulb present; genital atrium muscular, penis conical, armed with crown of hooks. Ovary near middle of body, shaped as inverted U. Vaginal opening double, ventrolateral, posterior to genital atrium. Genito-intestinal canal short, communicating with intestinal branch. Vitelline fields co-existing with intestine. Egg with polar filament on each pole. Parasites on gills 
of the Carangidae. Type- species: Allogastrocotyle bivaginalis Nasir \& Fuentes Zambrano, 1983 ex Trachurus lathami, Venezuela.

\section{Discussion}

Costa et al. (2017) listed all parasites of fishes of the genus Trachurus. Monogeneans include: in T. lathami: A. bivaginalis and Pseudaxinoides cariacoensis Nasir \& Fuentes Zambrano, 1983; in T. picturatus: Cemocotyle trachuri Dillon \& Hargis, 1965 and Diplectanotrema trachuri Kovaleva, 1970. Three monogenean species were recorded from both fish species: Gastrocotyle trachuri van Beneden \& Hesse, 1863, Pseudaxine trachuri and Heteraxinoides atlanticus Gaevskaya \& Kovaleva, 1979.

Allogastrocotyle was originally described by Nasir \& Fuentes Zambrano (1983), to accommodate A. bivaginalis from Trachurus lathami, off Venezuela, Western Atlantic. This genus was mainly characterised by having two ventro-lateral vaginal openings. The type- and only species remains poorly known and has never been recorded again; it has, however, been mentioned in lists (Cohen et al., 2013; Eiras et al., 2016; Costa et al., 2017). Interestingly, some parasitological surveys on its host, T. lathami, did not record it (Braicovich et al., 2012; da Silva et al., 2012), suggesting it is rare.

Our specimens from T. picturatus in the southern Mediterranean unquestionably belong to the genus Allogastrocotyle, as shown by key features such as body shape and the number of vaginal openings. We are aware of the existence of Pseudaxinoides Lebedev, 1968, which has a similar body shape but, allegedly, multiple vaginal openings (Lebedev, 1968). We examined specimens of monogeneans corresponding to the definition of Pseudaxinoides, confirm here that they are different from Allogastrocotyle, but will discuss their taxonomic position in detail in a future paper. Our present molecular study showed that our specimens were different from Pseudaxine trachuri and thus support the validity of Allogastrocotyle (with two vaginal openings) vs Pseudaxine (no vaginal opening); however, we acknowledge that the number of species in the molecular analysis was low.

The question is whether our specimens from T. picturatus from Algeria are conspecific with $A$. bivaginalis, described from another host (T. lathami) and from a distant location (off Venezuela, Western Atlantic). In Fig. 7, we mapped the distribution of both fish species, which do not overlap. A comparison of our specimens with the original description did show some differences in clamp structure, which could 
be used for erecting a new species; however, examination of the holotype of A. bivaginalis did not allow to confirm these differences. We did obtain molecular information for our specimens, but molecular information is lacking for A. bivaginalis from its type- locality. This situation is very similar to that encountered by Chaabane et al. (2016a) who found a species morphologically similar to the diplectanid monogenean Pseudorhabdosynochus sulamericanus Santos, Buchmann \& Gibson, 2000 in the Mediterranean; the hosts were different (Hyporthodus haifensis in the Mediterranean vs H. niveatus and H. nigritus in the Western Atlantic); morphological differences were subtle and did not allow to erect a new species; molecular information was available for the Mediterranean specimens but not for the specimens from the Western Atlantic (Santos et al. 2000; Kritsky et al. 2015; Chaabane et al., 2016a). Chaabane et al. (2016a) concluded by ascribing their specimens to P. sulamericanus and discussed the problem of monogeneans which have been mentioned under the same binomial on both sides of the Atlantic; they remarked that no case of conspecific monogenean on both sides of the Atlantic had been demonstrated so far by both morphological and molecular methods, and this is still the case now.

Finally, due to overlapping in measurements and counts, we consider that the species of Allogastrocotyle from T. lathami and T. picturatus are conspecific, do not describe a new species, and record A. bivaginalis off Algeria, Mediterranean, on a new host, T. picturatus; this is the second record of this species, and of the genus, in the literature.

However, we believe that it is likely that future study will show that the species from the Mediterranean is a distinct species; this would require a detailed morphological and molecular study of specimens from the Western Atlantic.

\section{Acknowledgements}

We are greatly indebted to Anna Phillips from the United States National Museum, Washington, for kindly loaning the holotype. Professor Ken MacKenzie kindly provided literature. Our thanks are due to fishermen from Regaiia and especially Mohamed Kayrouze and Houcine. This work was funded by FSB, USTHB, Algeria, and ISYEB, MNHN, France. 
Table 1. Species used in the present molecular study. a New sequences; b Sequences published on GenBank only

\begin{tabular}{|c|c|c|c|c|}
\hline Parasite species & Host species & Origin & GenBank ID & Source \\
\hline Allogastrocotyle bivaginalis & Trachurus picturatus & Algeria & MN192391 ${ }^{\mathrm{a}}$ & \\
\hline Allogastrocotyle bivaginalis & Trachurus picturatus & Algeria & MN192392 ${ }^{\mathrm{a}}$ & \\
\hline $\begin{array}{l}\text { Pellonicola elongatus } \\
\text { Unnithan, } 1967\end{array}$ & Ilisha megaloptera & India & KU872043 & Unpublished \\
\hline $\begin{array}{l}\text { Engraulicola thrissocles } \\
\text { (Tripathi, 1959) Lebedev, } 1971\end{array}$ & Thryssa hamiltonii & India & KU872046 ${ }^{\mathrm{b}}$ & Unpublished \\
\hline $\begin{array}{l}\text { Pseudaxine trachuri } \\
\text { Parona \& Perugia, } 1889\end{array}$ & Trachurus trachurus & France & AY009168 & $\begin{array}{l}\text { Jovelin \& Justine } \\
(2001)\end{array}$ \\
\hline $\begin{array}{l}\text { Pseudaxine trachuri } \\
\text { Parona \& Perugia, } 1889\end{array}$ & Trachurus trachurus & Algeria & $\mathrm{MN} 192393^{\mathrm{a}}$ & Present study \\
\hline $\begin{array}{l}\text { Pseudaxine trachuri } \\
\text { Parona \& Perugia, } 1889\end{array}$ & Trachurus trachurus & Algeria & MN192394 ${ }^{\mathrm{a}}$ & Present study \\
\hline $\begin{array}{l}\text { Gotocotyla acanthura (Parona \& } \\
\text { Perugia, 1896) Meserve, } 1938\end{array}$ & $\begin{array}{l}\text { Scomberomorus } \\
\text { niphonius }\end{array}$ & China & KF826085 & Shi et al. (2014) \\
\hline Gotocotyla sawara Ishii, 1936 & $\begin{array}{l}\text { Scomberomorus } \\
\text { niphonius }\end{array}$ & China & KF739594 & Shi et al. (2014) \\
\hline
\end{tabular}


Table 2. Distances (in \%) between taxa (Kimura-2 parameter model)

\begin{tabular}{|l|l|c|l|l|l|l|l|l|l|}
\hline & Sequence ID, species and host & $\mathbf{1}$ & $\mathbf{2}$ & $\mathbf{3}$ & $\mathbf{4}$ & $\mathbf{5}$ & $\mathbf{6}$ & $\mathbf{7}$ & $\mathbf{8}$ \\
\hline 1 & KF739594.1 Gotocotyla sawara ex Scomberomorus niphonius & & & & & & & & \\
\hline 2 & KF826085.1 Gotocotyla acanthura ex Scomberomorus niphonius & 13 & & & & & & & \\
\hline 3 & MN192392 Allogastrocotyle bivaginalis ex Trachurus picturatus & 25 & 26 & & & & & & \\
\hline 4 & MN192391 Allogastrocotyle bivaginalis ex Trachurus picturatus & 25 & 26 & 0 & & & & & \\
\hline 5 & MN192394 Pseudaxine trachuri ex Trachurus trachurus & 26 & 25 & 18 & 18 & & & & \\
\hline 6 & MN192393 Pseudaxine trachuri ex Trachurus trachurus & 26 & 24 & 17 & 17 & 1 & & & \\
\hline 7 & AY009168.1 Pseudaxine trachuri ex Trachurus trachurus & 26 & 25 & 18 & 18 & 0 & 1 & & \\
\hline 8 & KU872046.1 Engraulicola thrissocles ex Thryssa hamiltonii & 24 & 25 & 22 & 22 & 19 & 19 & 19 & \\
\hline 9 & KU872043.1 Pellonicola elongatus ex Ilisha megaloptera & 27 & 23 & 23 & 23 & 22 & 22 & 22 & 20 \\
\hline
\end{tabular}

Table 2. Distances (in \%) between taxa (p-distances).

\begin{tabular}{|l|l|c|c|c|c|c|c|c|c|}
\hline & Sequence ID, species and host & $\mathbf{1}$ & $\mathbf{2}$ & $\mathbf{3}$ & $\mathbf{4}$ & $\mathbf{5}$ & $\mathbf{6}$ & $\mathbf{7}$ & $\mathbf{8}$ \\
\hline 1 & KF739594.1 Gotocotyla sawara ex Scomberomorus niphonius & & & & & & & & \\
\hline 2 & KF826085.1 Gotocotyla acanthura ex Scomberomorus niphonius & 12 & & & & & & & \\
\hline 3 & MN192392 Allogastrocotyle bivaginalis ex Trachurus picturatus & 21 & 22 & & & & & & \\
\hline 4 & MN192391 Allogastrocotyle bivaginalis ex Trachurus picturatus & 21 & 22 & 0 & & & & & \\
\hline 5 & MN192394 Pseudaxine trachuri ex Trachurus trachurus & 22 & 21 & 16 & 16 & & & & \\
\hline 6 & MN192393 Pseudaxine trachuri ex Trachurus trachurus & 22 & 21 & 15 & 15 & 1 & & & \\
\hline 7 & AY009168.1 Pseudaxine trachuri ex Trachurus trachurus & 22 & 21 & 16 & 16 & 0 & 1 & & \\
\hline 8 & KU872046.1 Engraulicola thrissocles ex Thryssa hamiltonii & 21 & 21 & 19 & 19 & 17 & 17 & 17 & \\
\hline 9 & KU872043.1 Pellonicola elongatus ex Ilisha megaloptera & 22 & 20 & 20 & 20 & 19 & 19 & 19 & 18 \\
\hline
\end{tabular}


Table 4. Measurements of Allogastrocotyle bivaginalis from various hosts and localities.

\begin{tabular}{|c|c|c|c|}
\hline Hosts & Trachurus picturatus & Trachurus lathami & Trachurus lathami \\
\hline Locality & $\begin{array}{l}\text { Off Algeria, } \\
\text { Mediterranean Sea }\end{array}$ & Off Venezuela, Atlantic & Off Venezuela, Atlantic \\
\hline No. of specimens & $\mathbf{n}=\mathbf{3 3}$ & 2 specimens measured & Holotype \\
\hline Source & Present study & $\begin{array}{l}\text { Nasir \& Fuentes } \\
\text { Zambrano (1983) }\end{array}$ & Present study \\
\hline Total body length & $\begin{array}{l}1,180-2,680(2,030 ; n= \\
26)\end{array}$ & $1,750-2,205$ & 1,760 \\
\hline Body width & $310-1,930(480 ; \mathrm{n}=26)$ & $455-495$ & 420 \\
\hline Haptor length & $\begin{array}{l}310-1,870(1,143 ; \mathrm{n}= \\
26)\end{array}$ & 945 & 945 \\
\hline Lappet length & & $100-130$ & \\
\hline $\begin{array}{l}\text { Prohaptoral suckers } \\
\text { length }\end{array}$ & $20-40(29 ; \mathrm{n}=28)$ & $16-26$ & 20 \\
\hline $\begin{array}{l}\text { Prohaptoral suckers } \\
\text { width }\end{array}$ & $15-50(29 ; n=28)$ & $18-22$ & 20 \\
\hline Pharynx length & $30-50(38 ; n=24)$ & 54 & 30 \\
\hline Pharynx width & $20-52(36 ; \mathrm{n}=24)$ & 58 & 27 \\
\hline Clamps number & $23-36(32 \pm 3 ; \mathrm{n}=29)$ & $32-33$ & 32 \\
\hline Clamp length & $37-68(55 \pm 7 ; \mathrm{n}=48)$ & $50-56$ & 55 \\
\hline Clamp width & $31-68(42 \pm 6 ; \mathrm{n}=46)$ & $41-44$ & 33 \\
\hline Small anchor & $9-13(11 ; n=19)$ & & 13 \\
\hline Long anchor & $24-32(29 ; \mathrm{n}=20)$ & $30-34$ & 33 \\
\hline Genital atrium length & $25-50(38 \pm 6 ; n=30)$ & & 37 \\
\hline Genital atrium width & $25-50(39 \pm 5 ; \mathrm{n}=30)$ & & 30 \\
\hline Number of atrial hooks & $11-13(12 ; \mathrm{n}=20)$ & 12 & 12 \\
\hline Atrial hooks length & $13-25(21 \pm 3 ; \mathrm{n}=41)$ & $17-20$ & 30 \\
\hline $\begin{array}{l}\text { Distance genital atrium- } \\
\text { anterior end }\end{array}$ & $125-310(206 ; n=27)$ & $134-216$ & 160 \\
\hline $\begin{array}{l}\text { Distance vagina-anterior } \\
\text { end }\end{array}$ & $180-480(303 ; n=26)$ & & 220 \\
\hline Distance vagina-atrium & $35-115(74 ; n=24)$ & & 25 \\
\hline Egg length & & 80 & \\
\hline Egg width & & 28 & \\
\hline
\end{tabular}


Figure 1. Molecular phylogenetic analysis by the Maximum Likelihood method based on the Hasegawa Kishino-Yano - model [1] of cox1 sequences of monogeneans. Bootstrap percentages (1,000 replicates) are indicated next to the branches when significant. There were a total of 299 positions in the final dataset. The Neighbour-Joining tree had similar topology and is not shown

Figure 2. Holotype of Allogastrocotyle bivaginalis Nasir \& Fuentes Zambrano, 1983 (USNM 1371132). A, Whole body; anteriormost clamp lacking; B, Anterior extremity showing relative positions of prohaptoral suckers, pharynx, genital atrium and lateral vaginal openings; C, Genital atrium (obliquely oriented); D, Posterior lappet

Figure 3. Allogastrocotyle bivaginalis from Trachurus picturatus, vouchers with associated molecular information. Upper row: general shape of body; lower row: clamp. A, B, Voucher MNHN HEL1091, GenBank: MN192391); C, D, voucher MNHN HEL1092, GenBank: MN192392)

Figure 4. Allogastrocotyle bivaginalis from Trachurus picturatus. A, Whole body (MNHN HEL1095); B, Terminal lappet (MNHN HEL1100); C, Peduncles of clamps (MNHN HEL1099); D, Anchors, large anteriormost pair (MNHN HEL1091); E, Anchors, small posteriormost pair (MNHN HEL1091). F-I, Various aspects of genital atrium and variable position of penis; F, Penis, invaginated (MNHN HEL1096); G, Penis, evaginated (MNHN HEL1091); H, Penis, invaginated; I, Genital atrium, evaginated penis and male canal (MNHN HEL1101). J, Egg. D, Anchors of anteriormost pair; E, Anchors of posteriormost pair

Figure 5. Allogastrocotyle bivaginalis from Trachurus picturatus. Detail of anatomy of reproductive organs in the region of ovary (MNHN HEL1100). Abbreviations: C.v., common vitelloduct; G.i.c., genito-intestinal canal; I., intestine; O.m.i., ovary immature part; O. m. p., ovary mature part; Oo., ootype; O., oviduct; T., testes; T.v., transverse vitelloducts; V., vitellarium; U., uterus 
Figure 6. Allogastrocotyle bivaginalis from Trachurus picturatus. Clamp (MNHN HEL1097). A, Dorsal view; B, Ventral view

Figure 7. Geographical distribution of Trachurus lathami and Trachurus picturatus in the Atlantic Ocean and Mediterranean Sea, and localities where specimens of Allogastrocotyle bivaginalis were collected. Trachurus picturatus is known from the Eastern Atlantic from Bay of Biscay to southern Morocco, Madeira, Azores, Canary Islands, Western Mediterranean. Trachurus lathami is a reef- associated, Western Atlantic species, from Canada to Maine, northern Gulf of Mexico to northern Argentina (Costa et al., 2017). The distributions of the two host species do not overlap 


\section{References}

Ayadi, Z. E. M., Gey, D., Justine, J.-L., \& Tazerouti, F. (2017). new species of Microcotyle (Monogenea: Microcotylidae) A new species of Microcotyle (Monogenea: Microcotylidae) from Scorpaena notata (Teleostei: Scorpaenidae) in the Mediterranean Sea. Parasitology International, 66, 37-42.

Bouguerche, C., Gey, D., Justine, J.-L., \& Tazerouti, F. (2019a). Microcotyle visa n. sp. (Monogenea: Microcotylidae, a gill parasite of Pagrus caeruleostictus (Valenciennes) (Teleostei: Sparidae) off the Algerian coast, Western Mediterranean. Systematic Parasitology, 96, 131-147.

Bouguerche, C., Gey, D., Justine, J.-L., \& Tazerouti, F. (2019b). Towards the resolution of the Microcotyle erythrini species complex: description of Microcotyle isyebi n. sp. (Monogenea, Microcotylidae) from Boops boops (Teleostei, Sparidae) off the Algerian coast. Parasitology Research, 118, 1417-1428.

Bowles, J., Blair, D., \& McManus, D. P. (1995). A molecular phylogeny of the human schistosomes. Molecular Phylogenetics and Evolution, 4, 103-109.

Braicovich, P. E., Luque, J. L., \& Timi, J. T. (2012). Geo- graphical patterns of parasite infracommunities in the rough scad, Trachurus lathami Nichols, in the Southwestern Atlantic Ocean. Journal of Parasitology, 98, 768-777.

Chaabane, A., Justine, J.-L., Gey, D., Bakenhaster, M. D., \& Neifar, L. (2016a). Pseudorhabdosynochus sulamericanus (Monogenea, Diplectanidae), a parasite of deepsea groupers (Serranidae) occurs transatlantically on three congeneric hosts (Hyporthodus spp.), one from the Mediterranean Sea and two from the western Atlantic. PeerJ, 4, e2233.

Chaabane, A., Neifar, L., Gey, D., \& Justine, J.-L. (2016b). Species of Pseudorhabdosynochus (Monogenea, Diplectanidae) from groupers (Mycteroperca spp., Epinephelidae) in the Mediterranean and Eastern Atlantic Ocean, with special reference to the "beverleyburtonae group" and description of two new species. PLoS One, 11, e0159886.

Chaabane, A., Neifar, L., \& Justine, J.-L. (2015). Pseudorhabdosynochus regius n. sp. (Monogenea, Diplectanidae) from the mottled grouper Mycteroperca rubra (Teleostei) in the Mediterranean Sea and Eastern Atlantic. Parasite, 22, 9.

Chaabane, A., Neifar, L., \& Justine, J.-L. (2017). Diplectanids from Mycteroperca spp. (Epinephelidae) in the Mediterranean Sea: Redescriptions of six species from material collected off Tunisia and Libya, proposal for the 'Pseudorhabdosynochus riouxi group', and a taxonomic key. PLoS One, 12, e0171392.

Cohen, S. C., Justo, M. C. N., \& Kohn, A. (2013). South American Monogenoidea parasites 
of Fishes, Amphibians and Reptiles: Published by the Authors

Costa, G., MacKenzie, K., \& Oliva, M. E. (2017). A review of the parasites infecting fishes of the genus Trachurus (Pisces: Carangidae). Reviews in Fisheries Science \& Aquaculture, 25, 297-315.

da Silva Gonçalves, P. H., \& Alves, D. R. (2012). Ecologia da comunidade de metazoários parasitos do xixarro, Trachurus lathami Nichols, 1920 (Osteichthyes: Carangidae) do litoral do Estado do Rio de Janeiro, Brasil. Cadernos UniFOA, 7, 105-113.

Derouiche, I., Neifar, L., Gey, D., Justine, J.-L., \& Tazerouti, F. (2019). Holocephalocotyle monstrosae n. gen., n. sp. (Monogenea, Monocotylidae) from the olfactory rosette of the rabbit fish, Chimaera monstrosa (Holocephali, Chimaeridae) in deep water off Algeria. Parasite, 26, 59.

Eiras, J. C., Velloso, A. L., \& Pereira, J. J. (2016). Parasitos de peixes marinhos da América do Sul. Rio Grande: Editora da FURG.

Fischer, W., Bauchot, M.-L., \& Schneider, M. (1987). Fiches FAO d'identification des espèces pour les besoins de la pêche. (Révision 1). Méditerranée et mer Noire. Zone de pêche 37. Volume II. Vertébrés. Publication préparée par la FAO, résultat d'un accord entre la FAO et la Commission des Communautés Européennes (Projet GCP/INT/422/ EEC) financée conjointement par ces deux organisations. Rome: FAO, pp. 761-1530.

Hargis, W. J. (1956). Monogenetic trematodes of Gulf of Mexico fishes. Part XII. The family Gastrocotylidae Price, 1943. Bulletin of Marine Science of the Gulf and Caribbean, 6, $28-43$.

Hasegawa, M., Kishino, H., \& Yano, T.-A. (1985). Dating of the human-ape splitting by a molecular clock of mitochondrial DNA. Journal of Molecular Evolution, 22, 160-174.

Jovelin, R., \& Justine, J.-L. (2001). Phylogenetic relationships within the polyopisthocotylean monogeneans (Platyhelminthes) inferred from partial 28S rDNA sequences. International Journal for Parasitology, 31, 393-401.

Justine, J.-L., Rahmouni , C., Gey, D., Schoelinck, C., \& Hoberg, E. P. (2013). The monogenean which lost its clamps. PLoS One, 8, e79155.

Kheddam, H., Justine, J.-L., \& Tazerouti, F. (2016). Hexabothriid monogeneans from the gills of deep-sea sharks off Algeria, with the description of Squalonchocotyle euzeti $\mathrm{n}$. sp. (Hexabothriidae) from the kitefin shark Dalatias licha (Euselachii, Dalatiidae). Helminthologia, 53, 354-362.

Kimura, M. (1980). A simple method for estimating evolutionary rates of base substitutions through comparative studies of nucleotide sequences. Journal of Molecular Evolution, $16,111-120$. 
Kritsky, D. C., Bakenhaster, M., \& Adams, D. (2015). Pseudorhabdosynochus species (Monogenoidea, Diplectanidae) parasitizing groupers (Serranidae, Epinephelinae, Epinephelini) in the western Atlantic Ocean and adjacent waters, with descriptions of 13 new species. Parasite, 22, 24.

Kumar, S., Stecher, G., \& Tamura, K. (2016). MEGA7: Molecular Evolutionary Genetics Analysis version 7.0 for bigger datasets. Molecular Biology and Evolution, 33, 18701874.

Lebedev, B. I. (1968). Monogeneans of fish of the New Zealand- Australian shelf in the South China Sea (Monogenoidea: Gastrocotylidae, Gastrocotylinae). In: Skrjabin, K. I. \& Mamaev, Y. L. (Eds), Helminths of animals of the Pacific Ocean. Moscow: Nauka.

Lebedev, B. I. (1986). [Monogenea: suborder Gastrocotylinea]. Leningrad: Nauka.

Littlewood, D. T. J., Rohde, K., \& Clough, K. A. (1997). Parasite speciation within or between host species? - Phylogenetic evidence from site-specific polystome monogeneans. International Journal for Parasitology, 27, 1289-1297.

Nasir, P., \& Fuentes Zambrano, J. (1983). Algunos tremátodos monogenéticos venezolanos. Rivista di Parassitologia, 44, 335-380.

Palombi, A. (1949). I Trematodi d'Italia: parte I. Trematodi Monogenetici. Archivio Zoologico Italiano, 34, 203-408 .

Price, E. W. North American monogenetic trematodes: VI. The family Diclidophoridae (Diclidophoroidea) (Diclidophoroidea). Journal of the Washington Academy of Sciences, 33, 44-54

Ratnasingham, S., \& Hebert, P. D. N. (2007). BOLD: The Barcode of Life Data System (www. barcodinglife. org). Molecular Ecology Notes, 7, 355-364.

Santos, C. P., Buchmann, K., \& Gibson, D. I. (2000). Pseudorhabdosynochus spp. (Monogenea : Diplectanidae) from the gills of Epinephelus spp. in Brazilian waters. System- atic Parasitology, 45, 145-153.

Shi, S.-F., Li, M., Yan, S., Wang, M., Yang, C.-P., Lun, Z.-R., et al. (2014). Phylogeography and demographic history of Gotocotyla sawara (Monogenea: Gotocotylidae) on Spanish mackerel (Scomberomorus niphonius) along the coast of China. Journal of Parasitology, 100, 85-92.

Sproston, N. (1946). A synopsis of the monogenetic trematodes. Transactions of the Zoological Society of London, 25, 185-600.

Ward, R. D., Zemlak, T. S., Innes, B. H., Last, P. R., \& Hebert, P. D. (2005). DNA barcoding Australia's fish species. Philosophical Transactions of the Royal Society of London B Biological Sciences, 360, 1847-1857. 
WoRMS (2019).Gastrocotylidae Price, 1943. http://www. marinespecies.org/aphia.php? $\mathrm{p}=$ taxdetails\&id $=119243$. Accessed on 12 July 
Figure 1

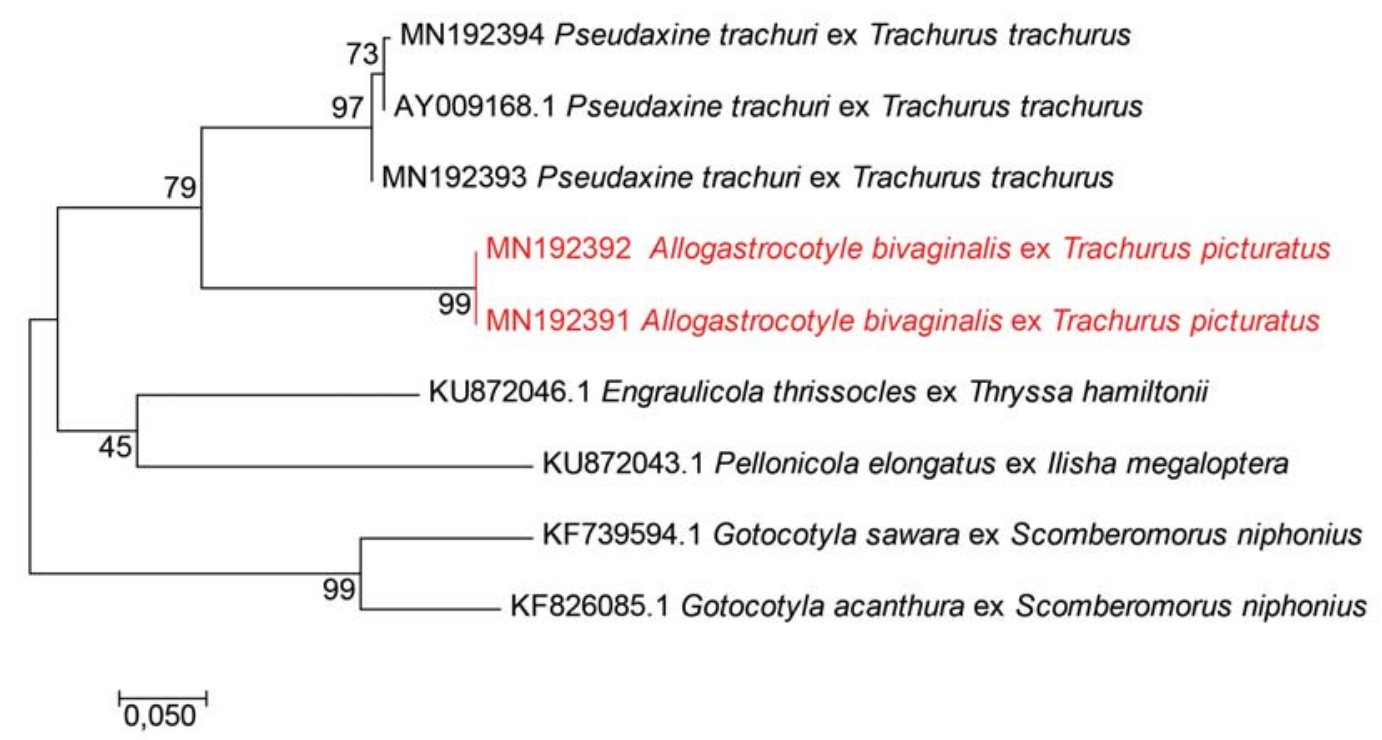


Figure 2

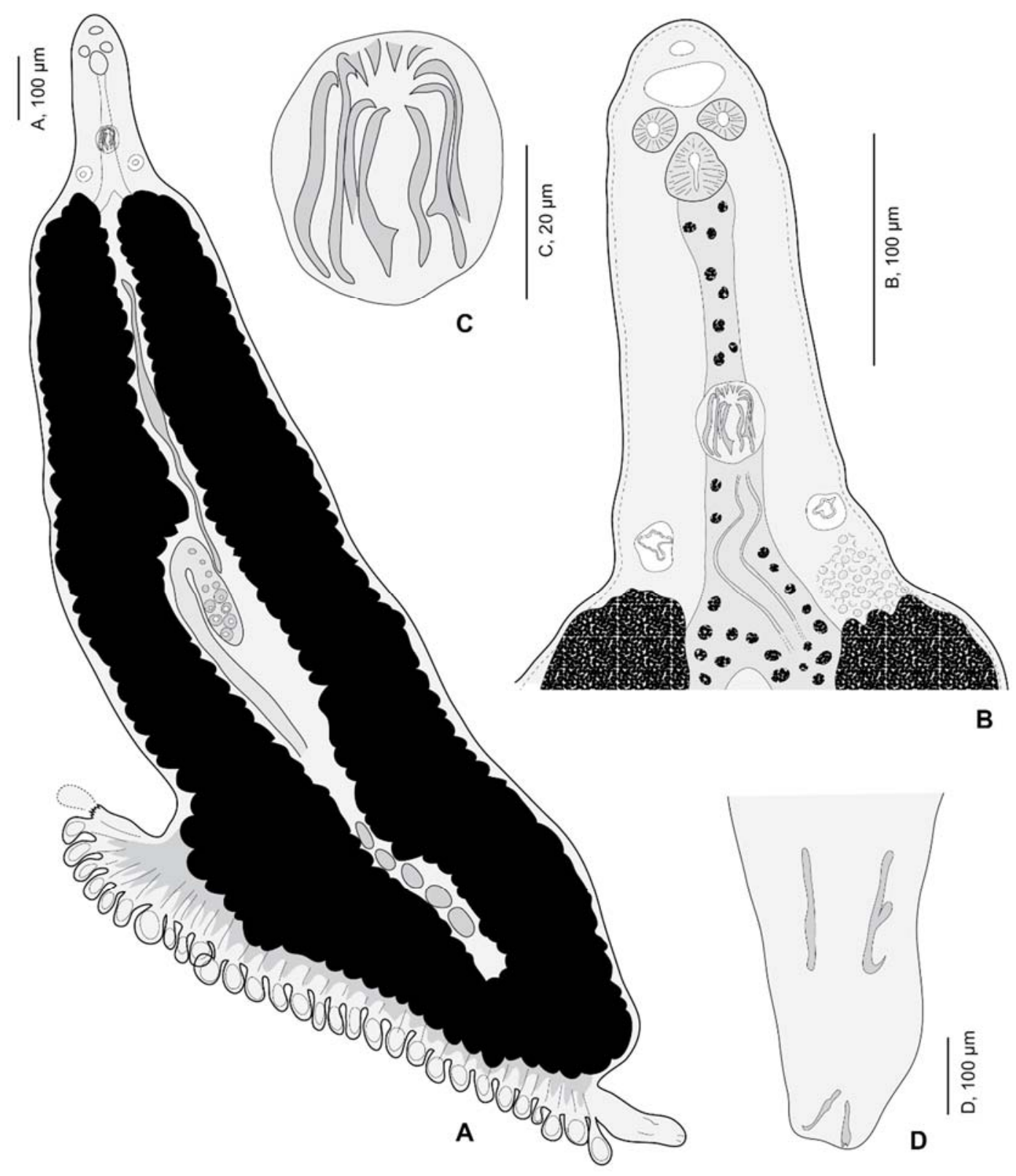


Figure 3
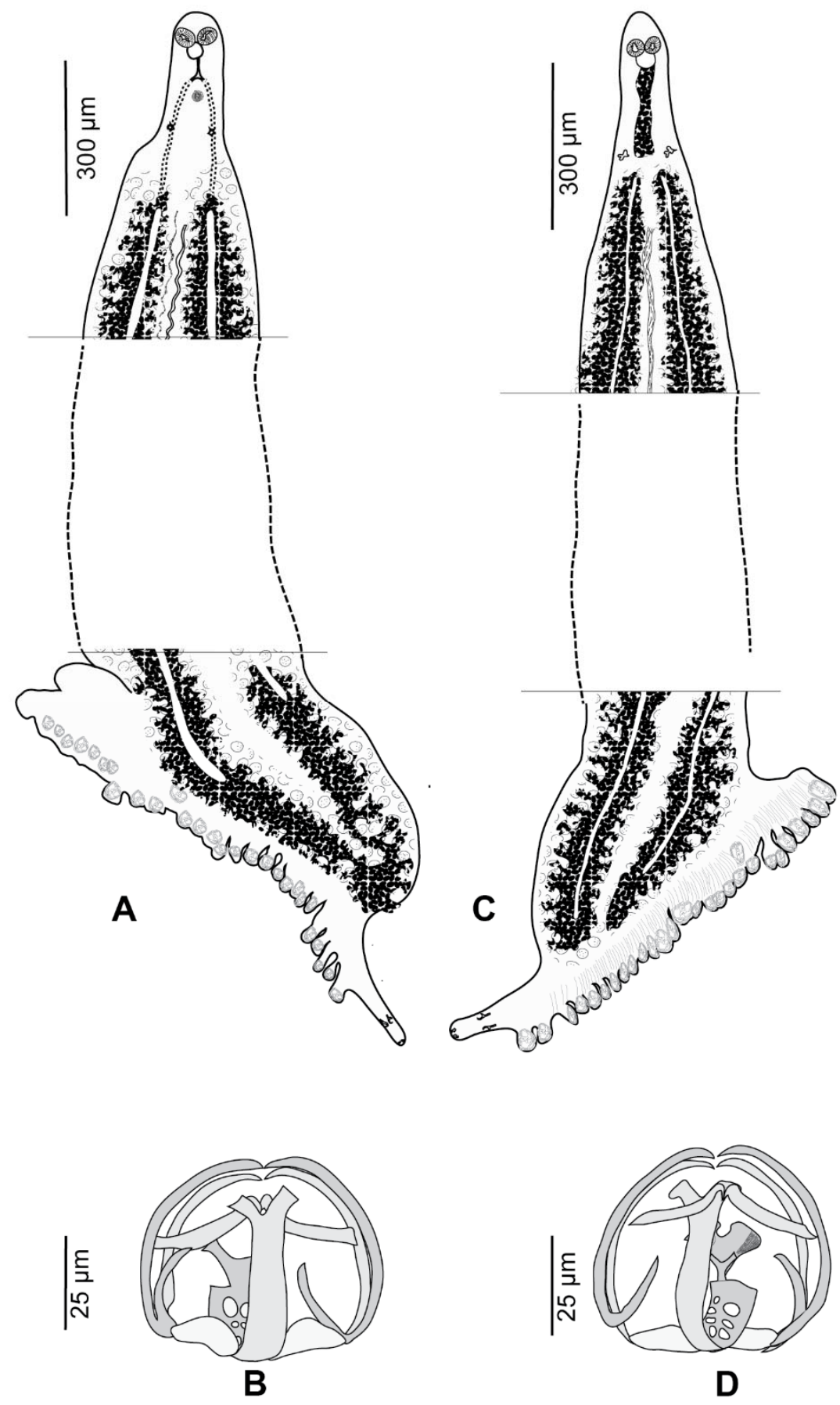
Figure 4

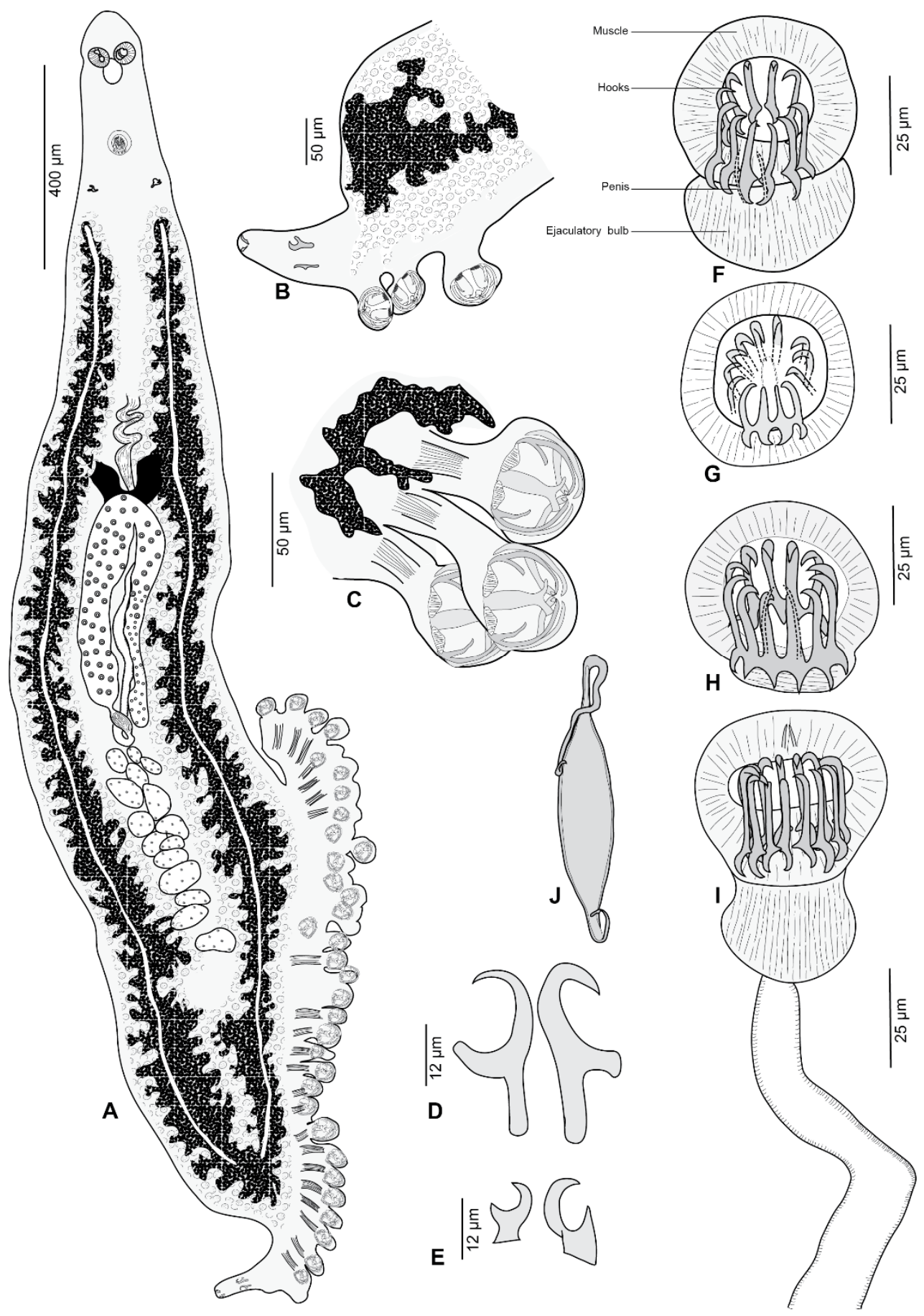


Figure 5

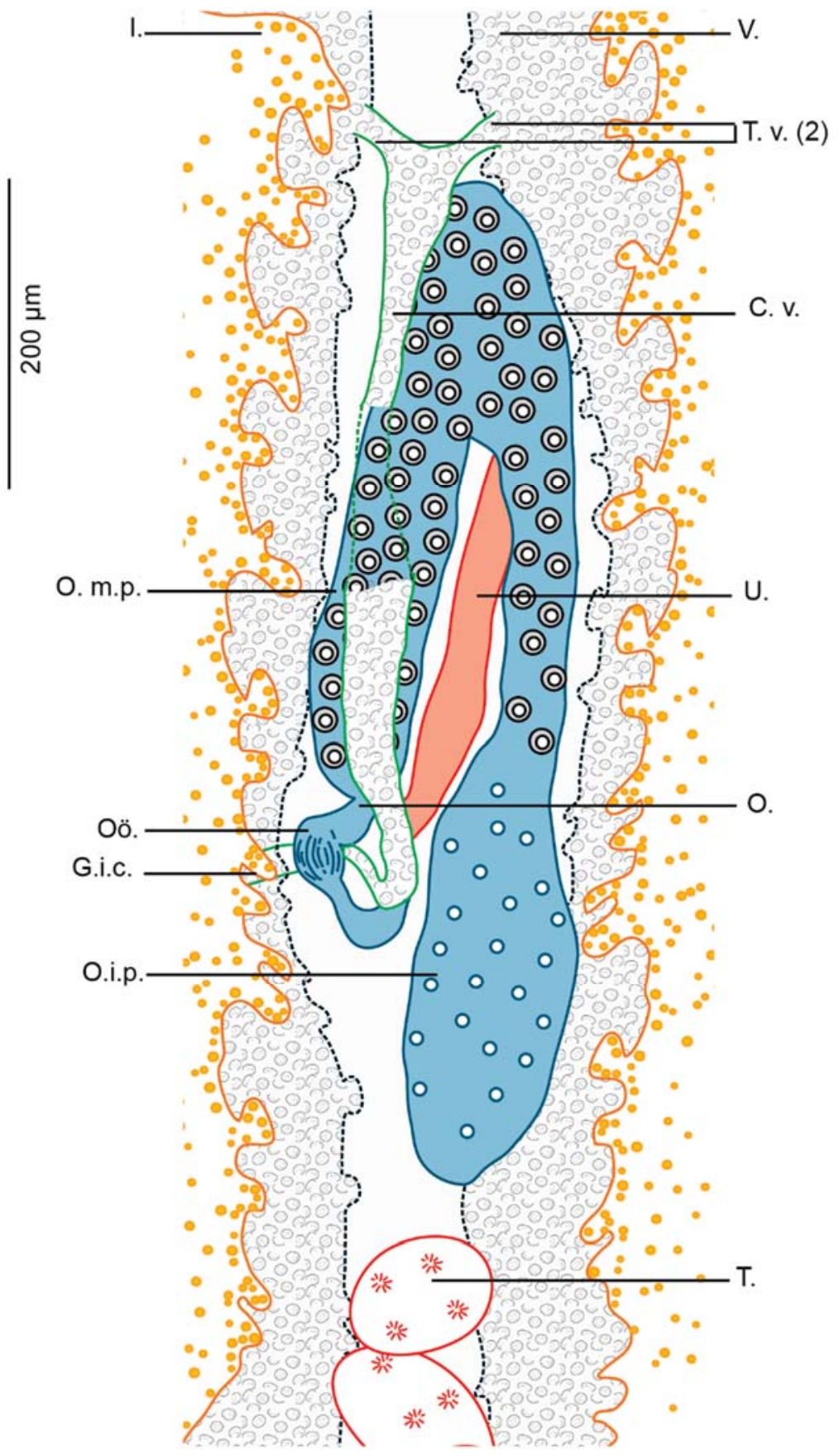


Figure 6
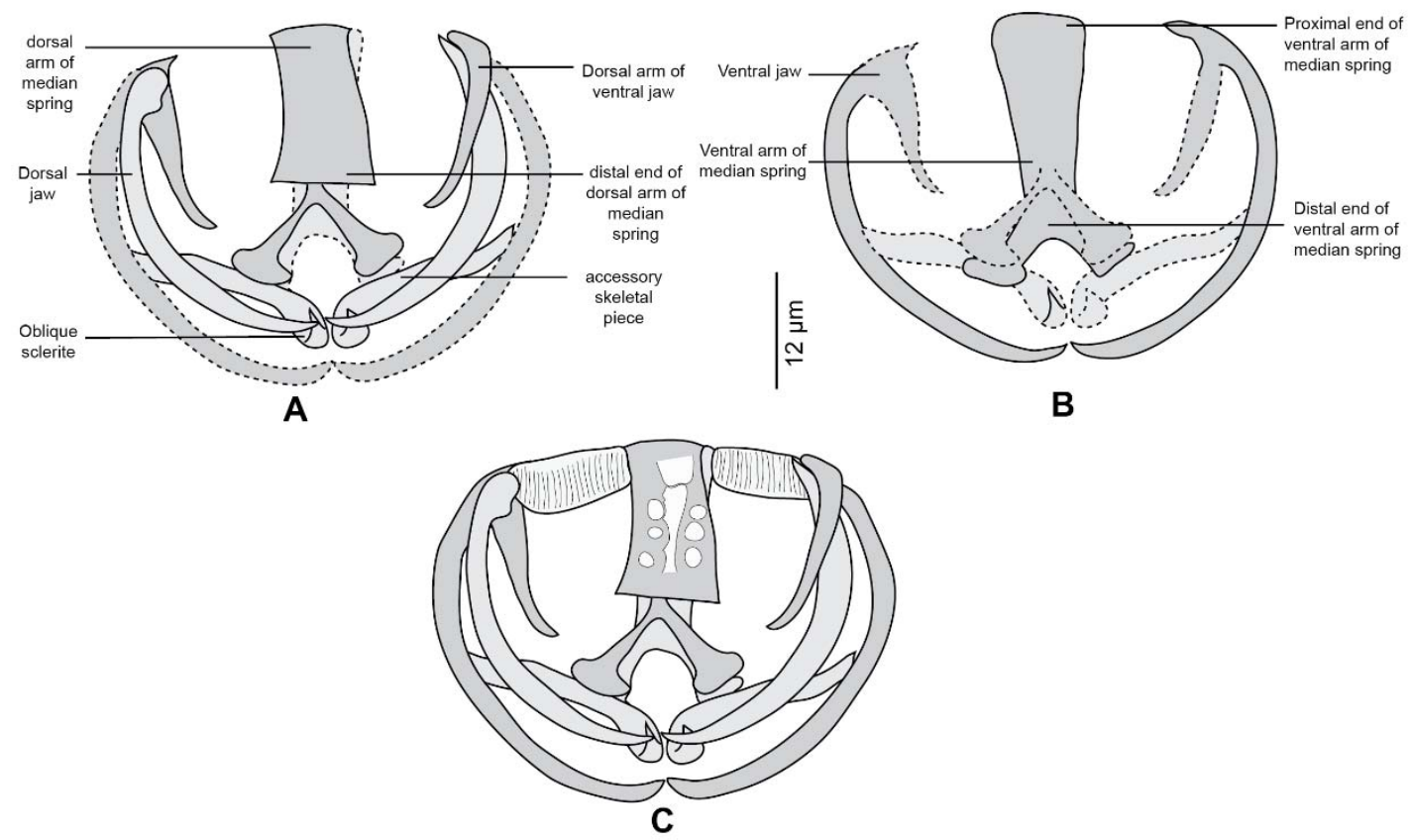
Figure 7

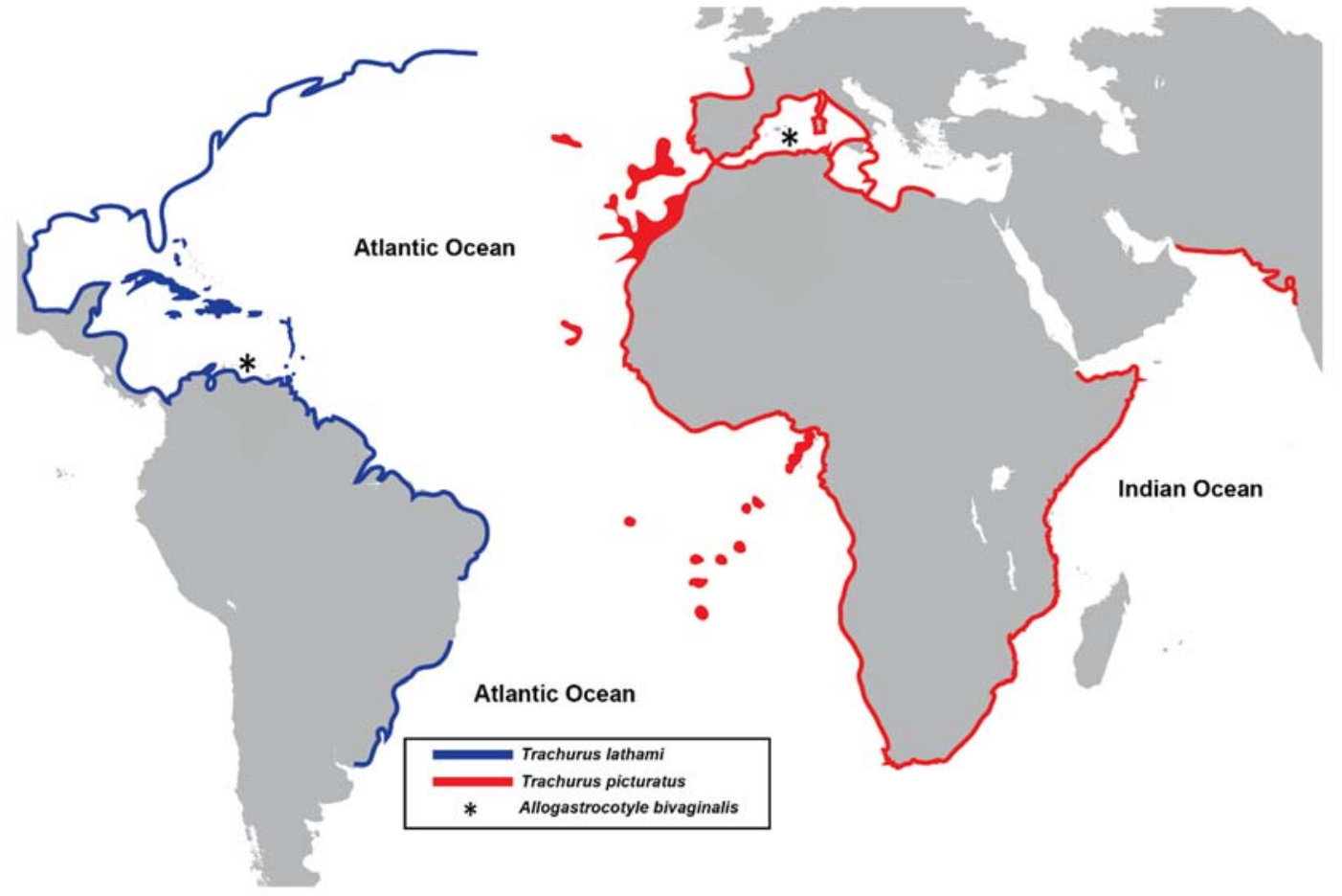

